\title{
Effect of Nitrogen, Phosphorus and Potassium Level on Morphological Characteristics of Chrysanthemum (Chrysanthemum morifolium Ramat) cv. Bidhan Madhuri
}

\author{
S. K. Senapati*, T. K. Das and G. Pandey \\ Department of Floriculture \& Landscaping, College of Agriculture, Orissa University of \\ Agriculture and Technology, Bhubaneswar-751003, Odisha, India \\ *Corresponding author
}

\section{A B S T R A C T}

\section{Keywords}

Chrysanthemum, Spray, Vegetative attributes, Height

\section{Article Info}

Accepted:

24 August 2020

Available Online:

10 September 2020

\begin{abstract}
An investigation entitled Effect of nutrient management in chrysanthemum (Chrysanthemum morifolium Ramat cv. BidhanMadhuri) was carried out at BTCC, OUAT, Bhubaneswar during winter 2017-18. The experiment was laid out in randomized block design (RBD) with comprising of eleven number of treatment combinations having different combinations of $\mathrm{N}, \mathrm{P}$ and $\mathrm{K}$ fertilizers $(\mathrm{Kg} / \mathrm{ha})$ which was replicated thrice in RBD. Among all the treatment, $\mathrm{T}_{10}$ having a fertilizer combinations of $\mathrm{N}=120, \mathrm{P}=125$, $\mathrm{K}=140 \mathrm{Kg} / \mathrm{ha}$ i.e. the optimum dose of fertilizer higher than that of the RDF $(\mathrm{N}=100$ $, \mathrm{P}=125, \mathrm{~K}=100 \mathrm{Kg} / \mathrm{ha}$ ) found to be effective in producing luxuriant and effective vegetative attributes i.e. maximum plant height $(66.253 \mathrm{~cm})$, East-West spread $(34.333 \mathrm{~cm})$, North-South spread $(32.526 \mathrm{~cm})$ while in case of number of spray per plant, treatment $T_{9}$ having a fertilizer combinations of $\mathrm{N}=120, \mathrm{P}=125, \mathrm{~K}=120 \mathrm{Kg} / \mathrm{ha}$ was found more promising. Hence it can be recommended for obtaining optimum vegetative growth yield attributes treatment having fertilizer combinations of $\mathrm{N}=120, \mathrm{P}=125, \mathrm{~K}=140 \mathrm{Kg} / \mathrm{ha}$ is suggested for Chrysanthemum crop in Bhubaneswar condition.
\end{abstract}

\section{Introduction}

Chrysanthemum (Chrysanthemum morifolium Ramat) is commonly known as Guldawdi, savent, Autumn Queen or Queen of the East and it belongs to family Asteraceae. This is one of the most important flowering plant, commercially grown in different parts of the world. Chrysanthemum is one of the most popular flowers grown in our country for its diversified beauty of colours, shapes, shades and keeping quality. Flowers symbolize purity, peace, love, beauty and passion. It was first cultivated in China and then spread to Japan. Hence, Chrysanthemum became the floral emblem of the imperial family of Japan and subsequently regarded as the National flower of Japan. Chrysanthemum flowers have diverse and beautiful range of colour shades and shapes making it suitable for every purpose conceivable for a flower crop that's why such flower is highly suitable for beds, pots and for floral arrangement. In India, chrysanthemum occupies a place of pride, both as commercial flower crop and as a popular exhibition flower. It is very popular 
as loose flower, cut flower as well as pot plant. For making garlands, veni, bracelets and in flower decoration and religious offering chrysanthemum is mostly used in our country. Due to wide range of colours, shapes and size of flowers it has gained tremendous popularity. Moreover, the utility and popularity of chrysanthemum has increased greatly with the technique of year-round blooming habit due to its ability to produce flowers round the year using cultivars based on their sensitivity to photoperiods. In recent years, demand of chrysanthemum for use in amenity horticulture has steadily increased not only for their aesthetic beauty and a long lasting quality but also for their good prospect of marketing as cut flowers and potted plants to many countries in the world (Bose et al., 2007). Though, for maximization of yield and quality of flower crop, various management practices like irrigation, plant density per unit area, season of growing, proper dose of manures and fertilizers, plant protection, etc. are to be properly maintained but balanced fertilizer application is considered as essential criteria for quality production of crops. It has been estimated that there is positive correlation between fertilizer usages and flower productivity. Cut chrysanthemum is a heavy feeder and has large requirement of nutrients. In modern days soil health is degraded due to many factors and it has been also observed that, one of the factors which mostly affects the yield and productivity of chrysanthemum crop is improper use of nutrients. To improve the productivity, adequate amount of fertilizers in balanced proportion should be used which has been given less attention by the flower growers or floriculturists. Improper nutrition leading towards nutrient imbalance in plant is a major factor contributing to low vegetative growth and low yield of flower. Under normal Agroclimatic conditions, the deficiency of major nutrients viz., $\mathrm{N}, \mathrm{P}$ and $\mathrm{K}$ is common and causes serious problems in proper vegetative growth and flower production. Hence, this research has been taken to study the different characteristics of Chrysanthemum under different doses of $\mathrm{N}, \mathrm{P}$ and $\mathrm{K}$.

\section{Materials and Methods}

A field experiment entitled "Effect of nutrient management in chrysanthemum (Chrysanthemum morifolium Ramat) cv. Bidhan Madhuri" was conducted at Biotechnology-cum-tissue culture center (BTCC) of O.U.A.T, Bhubaneswar. By giving a cut just below a node with a sharp knife, terminal herbaceous cuttings of 4-5 cm length were taken from the healthy mother plants of cultivar BidhanMaduri,. Then in a fine sand medium, they were inserted up to two third of its length. The healthy one month old rooted cuttings were transplanted in polythene bags consisting of soil. The well sprouted, rooted and vigorous cuttings were uplifted from nursery beds and carefully transplanted in each plot at the spacing of $30 \times 30 \mathrm{~cm}$ with a density of 16 plants per plot having net plot size $1.3 \mathrm{mx} 1.3 \mathrm{~m}$ after 45 days in month of November. The experiment comprised of eleven (11) treatments which replicated thrice and this experiment was laid out in a Randomized block design. Each treatment was composed of 16 plants and standard recommended packages of practices such as pinching weeding, watering were followed in each treatment. Pinching was done in 15 days interval in each treatment. Fertilization was done according to treatment. Nitrogen was applied in two splits i.e. $1 / 2$ at planting and rest $1 / 2$ at 30 DAP. All Potassium and Phosphorus in all treatments were applied as basal. Data just like height of flowers, East-West and North-South spreading, number of spray per plant 'observed from five randomly selected flowers from each plot at full bloom stage. The data obtained were averaged and computed. 


\section{Results and Discussion}

Maximum plant height of chrysanthemum $(66.253 \mathrm{~cm})$ was obtained in treatment number $\mathrm{T}_{10}$ having fertilizer combination of $\mathrm{N}=120$ $\mathrm{P}=125 \mathrm{~K}=140 \mathrm{~kg} / \mathrm{ha}$ and this was closely followed by treatment numbers $\mathrm{T}_{9}$ and $\mathrm{T}_{8}$ where plant heights of $64.807 \mathrm{~cm}$ and 63.547 $\mathrm{cm}$ were obtained having fertilizer combinations of $\mathrm{N}=120 \mathrm{P}=125 \mathrm{~K}=120 \mathrm{Kg}$ / ha and $\mathrm{N}=120 \quad \mathrm{P}=125 \quad \mathrm{~K}=120 \mathrm{Kg} / \mathrm{ha}$ respectively which were significantly superior to all other treatments. However, minimum plant height $(46.093 \mathrm{~cm})$ was noted in control treatment $\left(\mathrm{T}_{11}\right)$ having fertilizer combination $\mathrm{N}=0, \mathrm{P}=0, \mathrm{~K}=0$. These results may be due tohigher concentrations of Nitrogen which promoted the vegetative growth and dry matter accumulation. Also, the stimulating effects of $\mathrm{N}, \mathrm{P}$ and $\mathrm{K}$ may be due to activation of apical meristems besides the protoplasm formation, division and elongation of meristem cells and increase in the biosynthesis of carbohydrates and proteins which ultimately enhanced plant growth. These are in conformity with the findings of Kumar and Rana (2003)in Carnation cv. Chaubad Yellow, Sunita Devi et al., (2003) in carnation, Doddagoudar et. al. (2002) in China aster cv. Kamini, Kumar and Kumar (2014), Chavan (2006) and Sonalnath et al., (2010)in China aster. The increase in plant height is also due to the higher dose of nitrogen which might be due to nitrogen increases the transport of metabolites and rate of photosynthates in plant furthering as the rate of photosynthesis. Hence, it enables the plant to have quick and better upward vegetative growth and nitrogen has been also identified as an important constituent of chlorophyll, proteins and amino acids thereby enhancing the rate of photosynthesis. The increase in vegetative growth so thought might be due to greater uptake of nutrients into the plant system through soil application which finally involved in the cell division, cell elongation as well as protein synthesis which ultimately enhanced the stem length and vegetative growth. Similar kind of observations with an increase in vegetative growth by the external application of higher dose of fertilizers which was noticed by Joshi(2002), Patel(2004), Karavadia and Dhaduk (2002) in annual chrysanthemum, Shinde et al., (2014) in African marigold, Singh and Nigam (2015) and Nikam et al., (2018) in chrysanthemum.

Maximum East-west plant spread $(34.333 \mathrm{~cm})$ and North-south plant spread $(32.527 \mathrm{~cm})$ was obtained in treatment $\mathrm{T}_{10}$ having fertilizer combinations of $\mathrm{N}=120 \mathrm{P}=125 \mathrm{~K}=140 \mathrm{~kg} / \mathrm{ha}$ and this is due to the effect of Nitrogen on growth or spreading of plant as Nitrogen is an elementary constituent of amino acid, nucleic acid, proteins, proteids and nucleotides, chlorophyll and numerous secondary substances such as alkaloids which is an important constituent of the protoplasm and it involves in all enzymatic reactions taking place in cells and photosynthates transported to site of growth are used predominately in synthesis of nucleic acid and protein which enhances the cell expansion and that results in maximum spreading. Due to zero level application of nitrogenous fertilizer, minimum East-west plant spread $(21.301 \mathrm{~cm})$ and Northsouth plant spread $(18.553 \mathrm{~cm})$ was obtained in control treatment $\left(T_{11}\right)$. These results are in agreement with the finding of Sharma et al., (2006) Haque and Jakhro (2001). Potassium fertilization also have some roles in spreading as Potassium has a stimulating effect on the photosynthesis, phloem loading and translocation of carbohydrates as well as synthesis of large molecular weight substances. Similar observations were recorded in their earlier studies by Pal and Ghosh (2010) and Kishore et al., (2010) in African marigold. Nitrogen and potassium are the two important constituents of chlorophylls, proteins and amino acids hence 
increased level of nitrogen enhanced the rate of photosynthesis thereby increased cell division and cell elongation took place which ultimately enhanced the vegetative growth. Further, there was a better utilization of nitrogen in the presence of potassium as reflected in increasing the plant spread. The above results were in conformity with the earlier findings of Kumar et al., (2003) and Gnyandev (2006) in China aster (Table 1).

Table.1

\begin{tabular}{|c|c|c|c|c|}
\hline Treatments & $\begin{array}{c}\text { Plant } \\
\text { height }(\mathrm{cm})\end{array}$ & $\begin{array}{l}\text { North- South } \\
\text { spreading }(\mathbf{c m})\end{array}$ & $\begin{array}{c}\text { East-West } \\
\text { Spreading }(\mathbf{c m})\end{array}$ & Number of spray \\
\hline $\begin{array}{l}\text { T1 (RDF) } \\
(\mathrm{N}=100 \mathrm{P}=125 \mathrm{~K}=125)\end{array}$ & 61.393 & 30.100 & 29.920 & 2.133 \\
\hline $\begin{array}{l}\text { T2 } \\
(\mathrm{N}=80 \mathrm{P}=125 \mathrm{~K}=100)\end{array}$ & 55.647 & 25.393 & 26.040 & 1.400 \\
\hline $\begin{array}{l}\mathrm{T3} \\
(\mathrm{N}=80 \mathrm{P}=125, \mathrm{~K}=120)\end{array}$ & 56.767 & 26.846 & 27.340 & 1.733 \\
\hline $\begin{array}{l}T 4 \\
(N=80 \quad P=125 \quad K=140)\end{array}$ & 58.500 & 26.246 & 28.186 & 1.000 \\
\hline $\begin{array}{l}\text { T5 } \\
(\mathrm{N}=100 \mathrm{P}=125 \mathrm{~K}=100)\end{array}$ & 59.793 & 27.973 & 28.593 & 1.933 \\
\hline $\begin{array}{l}\text { T6 } \\
(\mathrm{N}=100 \mathrm{P}=125 \mathrm{~K}=120)\end{array}$ & 59.827 & 28.033 & 29.600 & 2.467 \\
\hline $\begin{array}{l}\text { T7 } \\
(\mathrm{N}=100 \mathrm{P}=125 \mathrm{~K}=140)\end{array}$ & 62.053 & 29.886 & 31.633 & 2.400 \\
\hline $\begin{array}{l}\text { T8 } \\
(\mathrm{N}=120 \mathrm{P}=125 \mathrm{~K}=100)\end{array}$ & 63.547 & 30.473 & 32.633 & 3.000 \\
\hline $\begin{array}{l}\text { T9 } \\
(\mathrm{N}=120 \mathrm{P}=125 \mathrm{~K}=120)\end{array}$ & 64.807 & 31.480 & 33.686 & 3.467 \\
\hline $\begin{array}{l}\text { T10 } \\
(\mathrm{N}=120, P=125 \mathrm{~K}=140)\end{array}$ & 66.253 & 32.526 & 34.333 & 2.933 \\
\hline $\begin{array}{l}\text { T11 } \\
(\mathbf{N}=\mathbf{0}, \mathbf{P}=\mathbf{0} \mathrm{K}=\mathbf{0})\end{array}$ & 46.093 & 18.533 & 21.301 & 0.667 \\
\hline SE $(\mathbf{m}) \pm$ & 0.912 & 1.403 & 14.230 & 0.075 \\
\hline C.D. at 5\% & 2.710 & 4.169 & 42.280 & 0.223 \\
\hline
\end{tabular}

Maximum number of spray $(3.467 \mathrm{~cm})$ was obtained in treatment $\mathrm{T} 9$ having fertilizer combinations $\mathrm{N}=120 \mathrm{P}=125 \mathrm{~K}=120 \mathrm{~kg} / \mathrm{ha}$ which was significantly superior over all other treatments due to the higher level of Nitrogen. Here, with the increase in level of Nitrogen, there is increase in number of sprays per plant as Nitrogen being a constituent of protoplasm, it involves in basic reaction of photosynthesis providing its role in total biomass production that bring significant growth in branching and secondly, the nitrogen supply to the roots is responsible to stimulate the production and export of cytokine to the shoots. The increased level of cytokine in plants due to higher nitrogen application rate might have caused the lateral buds to sprout producing more number of sprays per plant. Minimum number of spray $(0.223 \mathrm{~cm})$ was noted in control plot $\left(T_{11}\right)$ 
having fertilizer combination $\mathrm{N}=0 \mathrm{P}=0 \mathrm{~K}=0$ due to zero level application of Nitrogen. These results are in agreement with the findings of Joshi (2002) and Patel (2004).

In conclusion the results revealed that treatment $\mathrm{T}_{10}$ having a fertilizer combination $\mathrm{N}=120, \mathrm{P}=125, \mathrm{~K}=140 \mathrm{Kg} / \mathrm{ha}$ was found to be more effective in increasing the maximum vegetative growth parameters (plant height, plant spread) while in case of, number of spray per plant, treatment $\mathrm{T}_{9}$ having a fertilizer combinations of $\mathrm{N}=120, \mathrm{P}=125$, $\mathrm{K}=120 \mathrm{Kg} / \mathrm{ha}$ was found more promising So, it can be concluded that the optimum dose of fertilizer higher than the RDF where Phosphorus remains constant has resulted in incorporating a sound and luxuriant vegetative growth subsequently increasing the flower yield in Chrysanthemum in Bhubaneswar.

\section{References}

Bose T.K.., Yadav L.P.,Pal P., Das, P. and Parthasarsthy V.A. Commercial Flowers.Vol.1.Calcutta:Naya Prokash;2007.Chavan, M. D. (2006).

Chavan, M.D., Jadhav P.B. and Rugge, V.C.(2010). Performance of China aster [Callistephuschinensis (L.) Nees] varieties and their response to different levels of nitrogen. M.Sc. (Hort.) Thesis, Junagadh Agricultural University, Junagadh, GUJARAT (INDIA).

Doddagoudar SR, Vyakaranahal BS, Shekhargouda M, Naliniprabhakar AS and Patil VS. 2002. Effect of mother plant nutrition and chemical spray on growth and seed yield of China aster cv. 'Kamini'. Seed-Research 30(2): 269274.

Gnyandev, B. (2006). Effect of pinching, plant nutrition and growth retardants on seed yield, quality and storage studies in China aster (Callistephus chinensis
L. Nees.). M. Sc. (Agri.) Thesis submitted to University of Agricultural Sciences, Dharwad, Karnataka (India).

Haque I. and Jarkho A. Soil and fertilizer potassium. In: Soil science. Islamabad, Pakistan: Soil Science National Book Foundation: 2001:261-263.

Joshi VK. 2002. Nutritional requirement of chrysanthemum (Chrysanthemum morifolium Ramat.) cv. IIHR-6 under North Gujarat conditions, Thesis Submitted to Gujarat Agricultural University, Sardar Krushinagar.

Karavadia BN and Dhaduk BK.2002. Effect of spacing and nitrogen on annual chrysanthemum (Chrysanthemum coronarium) cv. Local White. $J$. Ornamental Hort, 5(1): 65-66.

Kishore, G. R., J. K. Arya and P. K. Ghalot (2010). Effect of different levels of nitrogen, phosphorus and potassium on growth and flowering of African marigold cv. PusaNarangiGainda. Progressive Agriculture, 82(6): 941-45.

Kumar, A. and Kumar, R. (2014). Effect of nitrogen and phosphorus levels on growth, flowering and yield of China aster (Calistephus chinensis) Plant Archives 14(1):475-477.

Kumar, J., S. S. Chavhan and D. V. Singh (2003). Response of $\mathrm{N}$ and $\mathrm{P}$ fertilization on china aster. Journal of Ornamental Horticulture, 6(1): 82.

Kumar J and Rana P. 2003. Response of nitrogen and IAA in spray carnation. Journal of Ornamental Horticulture, New series. 6(3): 285-286.

Nikam, B.S., S.A. Badge and Pawar A.R. 2018. Growth and seed yield of Annual chrysanthemum as influenced by Different levels of Nitrogen and Potassium. Int.J.Curr.Microbiol.App. Sci. 7(9): 563-568.

Pal P, Ghosh P. Effect of different sources and levels of Potassium on growth, flowering and yield of African marigold 
(Tagetes erecta linn) cv. Siracole. Indian Journal of Natural products and Resources.2010; 1(3)371-375.

Patel AP. 2004. Effect of nitrogen through urea and castor cake on growth, flowering and yield of chrysanthemum (Chrysanthemum morifolium Ram.) cv. IIHR-6, Thesis submitted to Junagadh Agricultural University, Junagadh.

Sharma, B.P., Y.D. Sharma and B.S. Dilta (2006).Studies of NPK nutrition on growth and flowering of chrysanthemum. International J. Plant Sci., 1(1): 32-35.

Shinde, Manisha, Khiratkar, S.D., Ganjure, Surekhaand Bahadure, Rohit, 2014. Response of nitrogen and potassium levels on growth and flowering and seed yield of African Marigold. J. Soils and Crops. 24(1): 89-94.

Singh, J. and Nigam Rashmi, 2015. Effect of PGRs and inorganic fertilizers on vegetative growth and flowering behaviour of chrysanthemum, HortiFlora Res. Spectrum. 4(3): 273-276.

Sonalnath, S.K., Gupta, A.K., Kumar, S. and Lather, R. (2010). Studies on effect of $\mathrm{N}$ and $\mathrm{P}$ on growth of China aster cv. PG WHITE. Haryana J. Hort. Sci., 39(3\&4): 298-299.

Sunita Devi, Gupta AK, Sehrawat SK and Devi S. 2003. Effect of different levels of nitrogen and phosphorous on the growth of carnation (Dianthus caryophyllus L.) cv. Cabaret. Haryana Journal of Horticultural Sciences, 32(34): 209-211.

\section{How to cite this article:}

Senapati, S. K., T. K. Das and Pandey, G. 2020. Effect of Nitrogen, Phosphorus and Potassium Level on Morphological Characteristics of Chrysanthemum (Chrysanthemum morifolium Ramat) cv. Bidhan Madhuri. Int.J.Curr.Microbiol.App.Sci. 9(09): 3283-3288. doi: https://doi.org/10.20546/ijcmas.2020.909.407 